\title{
Discursos meia-oito e o dialogismo em movimentos
}

Elmo Santos ${ }^{1}$

\begin{abstract}
This essay is part of studies developed about polemic, especially those committed to the dialogical approach. These studies were inspired on the discovery of some relevant Brazilian history events, as the 1968's thematic, with their revolutionary manifestations and movements. We propose a study based on the composition of the concrete utterance and the polemic dialogism, according to the indications of the Bakhtin Circle, that interacts in multiple dialogues with the speeches of resistance of 1968, in verbal and verbal-visual examples, still in motion.
\end{abstract}

Keywords:Discourse; dialogism; polemic; 1968

Resumo: O presente ensaio é parte de estudos desenvolvidos sobre a polêmica, especialmente aqueles comprometidos com a abordagem dialógica. Esses estudos foram inspirados na descoberta de alguns acontecimentos relevantes da história brasileira, como a temática de 1968, com seus revolucionários movimentos e manifestações. Propomos um estudo a partir da composição do enunciado concreto e do dialogismo polêmico, conforme as indicações do Círculo de Bakhtin, que interage em múltiplos diálogos com discursos de resistência de 1968, em exemplos verbais e verbo-visuais, ainda em movimento.

Palavras-Chave: Discurso; dialogismo; polêmica; 1968

Introdução

O título desse estudo sugere uma iniciativa ambiciosa de explicar o ano de 1968, discursivamente, em sua complexidade polêmica. A proposta, contudo, resume-se a uma vontade de adquirir conhecimentos sobre a polêmica, numa perspectiva dialógica, e fornecer respostas a determinados discursos e a consideráveis indagações sobre a leitura.

Com a expressão "discursos meia-oito", fazemos uma referência à produção discursiva da "geração 68", a um conjunto de textos reunidos em arquivo constituído a partir de 2018, quando das comemorações do cinquentenário de 1968, no mundo. Desde sempre, nutrimos um entusiasmo com a temática, bem como uma positividade do posicionamento crítico ante os acontecimentos ocorridos e movimentos em atividade naquele ano. As comemorações apresentaram a privilegiada oportunidade de leituras de muitos textos e multiplicidade de gêneros das barricadas do prazer e de todas as primaveras, principalmente, a brasileira. A emergência do estudo foi impulsionada por recentes acontecimentos que atualizam, explicitamente ou não, os eventos que abalaram o mundo. Desse conjunto de textos, constituímos um corpus de referência, do qual selecionamos alguns exemplos relevantes que dialogam com elementos teóricos e metodológicos que orientam o exercício, alguns movimentos de leitura.

1 Doutor em Semiótica e Linguística Geral (USP) e professor da Universidade Federal da Bahia (UFBA). 
Os "discursos meia-oito devem ser compreendidos como aqueles produzidos por movimentos sociais brasileiros, em 1968 ou que ao ano se referem, cuja produção se deixa surpreender nas movimentações da língua viva. Fica estabelecido, pois, que o objetivo mais específico ler textos, numa perspectiva dialógica e polêmica, acentuando a sua relevância na constituição de um saber discursivo da época e de seus ecos nas falas democráticas e revolucionárias de hoje. A vasta produção de textos que repercutem na vida social, nesse momento-já, alertam para a compreensão das práticas sociais de hoje, dentre as quais as práticas de linguagem, nessa atual realidade brasileira da fabricação de tantos fatos, supostas novas vozes e sentidos.

A linguagem é, pois, o objeto mais amplo e fundamental da investigação, especificada nos estudos dialógicos, nas redes conceituais do Círculo de Bakhtin. Referimo-nos a um movimento teórico iniciado com a Filosofia do Ato e Marxismo e filosofia da linguagem e que segue seu caminho ao encontro do enunciado, do heterodiscurso, da polifonia e da polêmica na obra de Dostoiévski. A análise proposta é do enunciado concreto, a unidade de comunicação discursiva, categoria fundamental dos estudo dialógicos. Este enunciado é surpreendido como ato responsável, responsivo, apreciativo e atuante. Além dos estudos deste círculo original, destacamos os trabalhos de variados grupos espalhados pelo mundo, como acontece no Brasil, que renovam e dinamizam a análise dialógica do discurso.

Na ordem metodológica, a situação da vida social é o primeiro elemento a ser definido e, por isso, há um grande interesse com a ciência da história, com documentos históricos, muito marcados pela situação, os monumentos. Dá-se, então, toda uma busca às fontes da historicidade como conhecimento necessário à leitura de textos/discursos, relação que envolve histórias, historiadores e historiografias. Além dessa situação histórica, são muito oportunas as sincronias apresentadas pela sociologia, porque as pessoas vivem em comunidades, em sociedades, que oferece uma discussão legítima sobre grupos sociais, movimentos sociais, conflitos e outras categorias necessárias para o conhecimento das dinâmicas práticas sociais. Por fim, valemo-nos dos conceitos da filosofia e ciência políticas, como poder, democracia, totalitarismo, liberdade, ditadura e tantos outros que invadem as leituras. Com isso, continuamos as buscas de caminhos para uma compreensão da situação da vida social, fonte produtora dos discursos, de movimentos, como os de 1968 .

Dizem cronistas e ensaístas que "os anos sessenta" mostraram uma revolução para o mundo e nunca passarão. História recente de ainda muitas testemunhas, estes anos continuam vivos com as pessoas, nos memoriais, na vasta produção textual e na memória de imagens marcantes para o mundo. No Brasil, esses anos não passaram porque houve um golpe, em 1964, ressignificado e intensificado em 1968. Esses documentos existem como registros que sobraram da época, da atuação de movimentos sociais, principalmente, o estudantil. O ano de 1968 marca uma ordem dos movimentos de resistência que dialogam com práticas, vozes e discursos que ocupam a cena política desde a Colônia até os dias atuais. É um ano que esteve e está no caminho daqueles que se interessam por momentos de tensão da história brasileira, como em um manifesto que acusava o rei de ladrão, em 1798, até as rupturas democráticas de hoje. Esse momento situa movimentos que encenam uma articulada reação ao imperialismo e à ditadura, produzem discursos para a sua época, mas estabelecem um diálogo com nosso tempo e falas emergentes no Brasil. É essa a maior importância de ler 1968, no nosso ponto de vista de hoje: "Para que nunca se esqueça, para que jamais aconteça". 
A nossa proposta destaca o lugar da abordagem dialógica entre as teorias/análises do discurso e dos estudos da linguagem em geral, num diálogo produtivo das transdiscursividades e outras campos dos estudos linguísticos e semióticos; estabelece relações dos estudos do discurso com as ciências humanas e sociais; destaca alguns princípios e funcionamentos da dialogicidade polêmica em textos produzidos em 1968. Esse direcionamento teórico-metodológico controla o entendimento das práticas discursivas e do dialogismo polêmico dos movimentos sociais de 1968, que se quer confirmar por meio de uma resposta ao AI5, de 1968, e outra às novas propagandas de um novo golpe político no Brasil, a partir de 2015.

\section{Enunciados e dialogismo polêmico em movimentos}

A emergência de intensos ruídos de violências verbais e falas autoritárias produzidos por sujeitos diversos conduzem a múltiplos questionamentos sobre os rumores da linguagem e o espaço da polêmica na vida e na arte, nos estudos enunciativos em geral e nos estudos dialógicos do discurso, em particular. Essa avaliação orienta para a um diálogo de múltiplas referências, dentre as quais Maingueneau - que afirma que o polêmico se revela um verdadeiro nó para a análise do discurso ${ }^{2}$-, Angenot, Kerbrat-Orecchioni, Zilberberg, Plantin, Amossi, Garand e outros que investigaram e investigam o assunto, independentemente da orientação teórica, pois todos compreendem a polêmica como uma tradução do discurso do outro. O diálogo com autores e obras permite a configuração de um contexto que pode validar o exame da polêmica na perspectiva da teoria/análise dialógica do discurso ${ }^{3}$.

Como dissemos, buscamos respostas sobre possibilidades de articulações entre estudos da linguagem e outras áreas, com o propósito de questionar abordagens e objetos, destacar e esclarecer os elementos constitutivos de enunciados concretos e polêmicos. A investigação das potencialidades de práticas/produção discursivas dos movimentos ou grupos sociais, mais os impactos dessa prática/produção na vida social constituem uma proposta que prevê considerações sobre o dialogismo polêmico e o enunciado que o constitui.

O enunciado concreto é definido como a unidade fundamental da comunicação discursiva (Bakhtin, 2003), categoria privilegiada para a reflexão sobre a linguagem e muito produtiva em leituras dialógicas do verbal, visual e verbo-visual. O enunciado concreto da vida cotidiana é, conforme Bakthin-Voloshinov (2004), Voloshinov (1981a, 1981b) e Bakhtin $(2003,1990,1981)$, unidade de comunicação e totalidade semântica, que se constitui e se organiza precisamente em uma interação verbal determinada e produzida por uma certa relação de comunicação social e cuja estrutura é determinada pela situação e o meio social. Nasce, vive e morre no processo de interação social entre os sujeitos participantes da enunciação. $\mathrm{O}$ enunciado é unidade de um determinado campo e interage com outros enunciados (Bakhtin, 2003). Os enunciados são atos de linguagem produzidos em situações da vida social e definidos por seus elementos extralinguísticos. Eis um breve sumário das potencialidades do enunciado concreto; eis o enunciado e o signo ideológicos.

2 Referimo-nos a "Registro: as três facetas do polêmico". Maingueneau, D. Doze conceitos em Análise do Discurso. São Paulo: Parábola, 2010.

3 Plantin (2003) propõe um debate sobre o espaço da polêmica ante as teorias da argumentação. Afirma que a argumentação polêmica busca mais converter, do que convencer e persuadir e que sobre isso as teorias da argumentação não dizem quase nada. Diz também que a análise do discurso permite melhor caracterizar a resposta polêmica da troca argumentativa. 
Em Bakhtin (2003) o autor afirma que toda compreensão do enunciado é de natureza ativamente responsiva e que toda compreensão é prenhe de resposta a enunciados precedentes de um determinado campo, rejeitando-os, confirmando-os e muitas outras reações ${ }^{4}$. Nessas formas típicas do gênero é que é formulado o desenho do discurso/ enunciado polêmico, que pode ser lido com base em um exame das ordens metodológicas indicadas pelos autores do Círculo, bem como nas leituras da obra literárias produzidas por Bakhtin: de um todo significativo, um ato produzido socialmente e que apresenta elementos linguísticos e extralinguísticos, a situação, o extraverbal da vida, a compreensão responsiva, o diálogo entre enunciados ${ }^{5}$. Esse relacionar-se com o outro constitutivo também situado, necessário à produção discursiva, oferece condições para uma investigação sobre a apreciação dialógica da consciência ideológica da produção e funcionamento de trocas verbais, como a polêmica.

Os objetivos teóricos do estudo do dialogismo em geral e, particularmente, do dialogismo polêmico, representam a vantagem de destacá-lo entre as possibilidades do discurso bivocal, para que assuma a sua importância na perspectiva na teoria/análise dialógica do discurso, como a modalidade que se pretende explorar na vida social de ontem e hoje 6 . A legenda "dialogismo polêmico" é entendida como um conjunto de práticas dialógicas e polêmicas, e do estudo dessas práticas, da modalidade, dessa produção de linguagem. É uma requalificação do trabalho da polêmica na arquitetura da obra do Círculo, para que lhe seja conferida a devida importância e reconhecido o seu papel entre as abordagens do assunto.

Em trabalho de revisão bibliográfica, buscamos avaliar aproximações e diferenças para destacar, no conjunto de textos de Bakhtin e Voloshinov, conhecimentos sobre o dialogismo polêmico em enunciados verbais, verbo-visuais e não verbais ${ }^{7}$. A perspectiva de estudos da linguagem e do dialogismo polêmico, essa construção muito particular do discurso e do gênero polifônico, está amparada, principalmente, nos escritos de Bakhtin (1981, 1990, 2003, 2005) e Bakhtin-Volochinov (2004). As referências à polêmica, nessas obras, podem ser explícitas ou estarem implícitas ou reveladas em práticas analíticas. Essa discussão está mais sistematizada em Bakhtin (1981), em que o autor sugere que a sua categorização dos gêneros bivocais poderia ser ampliada, o que permite um questionamento sobre a potência e a falência da polêmica.

Em Bakhtin-Volochinov (2004), afirma-se que cada palavra se apresenta como arena onde se entrecruzam e lutam valores sociais de orientação contraditória, como o produto

4 Estudos específicos sobre o enunciado concreto foram publicados, no Brasil, por Souza (1999) e Brait e Melo (2005). O primeiro discute a teoria no Círculo de Bakhtin, Volochinov e Medvedev; as autoras retomam a teoria e apresentam análises de alguns textos/discursos. São complementares e relevantes como introdução ao problema do enunciado e da enunciação.

5 Um breve inventário das ordens metodológicas de análise do signo ideológico e do enunciado concreto está apresentado em Bakhtin-Volochinov (2004); Voloshinov (1981, 1981a) e Bakhtin (2003). É possível verificar indicações metodológicas compõem a obra do Círculo, explícita ou implicitamente.

6 Um estudo importante para o entendimento da bivocalidade e modalidades discursivas, e da polêmica, está apresentado em Brait e Machado (2011). Nele, as autoras afirmam: "Polêmica interna velada é uma modalidade discursiva que se desdobra no discurso interior, mas não é vocalizada: parte do exterior, mas ressoa na mente do personagem".

7 Um modo de co(responder) a textos não verbais é a aproximação com as semióticas, as semiologias de Barthes e Courtine, entre muitas outras fontes, como a própria estética e teorias da arte. Os estudos e análises apresentados por Santaella (2002); Sataella e Nöth (2001), contribuem para esse fim. 
da interação viva das forças sociais. As forças sociais encontram expressão e elaboração ideológica nos níveis superiores da ideologia do cotidiano e que podem vir a se constituir em ideologia oficial ${ }^{8}$. Esse ponto de vista dialógico e ideológico, pressupõe as relações dialógicas polêmicas e as concebe como modalidade discursiva muito privilegiada, muito relevantes, nas práticas e nos estudos que lhes são dedicados.

De modo explícito, temos, em Bakhtin (1981), a constituição tipológica da polêmica, destacada de outros gêneros discursivos, configurada em níveis hierarquizados de intensidade/acento/tonalidade, numa escala definida pelo grau de aproximação e distanciamento entre os discursos, que lhes confere uma relação polêmica velada, aberta ou hostil e apresenta a possibilidade de passagem de um nível ao outro, muito estratégica. Segundo Brait e Machado, o trabalho sobre a polêmica é fundamental:

Esse é um momento bastante caro aos estudiosos da linguagem, na medida em que aí estão pontuados importantes aspectos para a compreensão do dialogismo, da questão das vozes, das formas e graus de presença do outro num dado discurso e de suas consequências (semânticas, estilísticas, enunciativas, discursivas) para a construção de sentidos na composição artística e na linguagem cotidiana. (BRAIT, B.; MACHADO, I., 2011, p. 31-32)

É correto lembrar que o ponto de partida do princípio dialógico é a contratualidade, embora o dissenso seja prática regular: tradução negativa, implícita ou de forma velada, ou um choque explícito entre objetos. Os gêneros bivocais/dialógicos, na proposta de Bakhtin (1981), delimitam uma troca verbal, de tipo argumentativo/retórico, intrínseca, extrínseca, estratégica e intencionalmente responsiva, apreciativa, conflituosa, constituída na negação do outro antagônico. Elementos extralinguísticos, mais os semânticos, sintáticos, pragmáticos, estilísticos e semióticos particularizam o dialogismo polêmico, em sua composição, seu funcionamento, práticas e valores constituídos. É a linguagem regulada por regras específicas de recusar o já-dito, o interdiscurso, a ideia outra. Polemizar, por essa visão, é um ato ético, responsivo, ativo, intencional, ideológico e combatente.

Contrários a essa liberdade discursiva, existem discursos cuja "intensidade polêmica" ou "acento polêmico" apresenta alto grau, numa saturação que reconstitui a cenografia da paixão e violência, que transforma o jogo em guerra, institui terceiros representados por força e poder, também essas as suas finalidades. Geralmente, esse tipo de discurso segue um funcionamento da polêmica hostil, que antecipa o outro para desfazê-lo, mas reconhece o discurso do outro. Já os discursos autoritários e totalitários, assumem outro espaço de fala, da não polêmica, para a sua falência, com consequências graves para o diálogo.

É desse espaço dos estudos dialógicos da polêmica que propomos interagir com alguns textos produzidos em 1968 ou em seu entorno, em diferentes suportes e gêneros. Um exercício de categorização de diálogos e enunciados, com destaque para um "tipo" de discurso que tem como princípio a negação de outro discurso, da ideia, dos valores, das

8 A concepção de ideologia está apresentada em Bakhtin-Volochinov (2004) e mais definida em Volochinov (2013): "Por ideologia entendemos o conjunto de reflexos e interpretações da realidade social e natural se se sucedem no cérebro do homem, fixados por meio das palavras, desenhos, esquemas ou outras formas sígnicas" (p. 138) (...) "Estabeleçamos o acordo de chamar de ideologia cotidiana a todo conjunto de sensações cotidianas - que refletem e refratam a realidade social objetiva - e as expressões exteriores imediatamente a elas ligadas“" (p. 151). 
ideologias do grupo, do movimento outro. O estudo do dialogismo polêmico tem, pois, como objeto o ato de polemizar do enunciado concreto e polêmico, verbal, verbo-visual e não verbal ${ }^{9}$.

Ao destacar as relações autor/discurso na prosa, Bakhtin (1990) diz que essa composição pressupõe uma percepção de concretude da palavra, tomada da luta social, ainda quente, não resolvida e dilacerada, participante das transformações. Essa palavra viva é o discurso, conforme Bakhtin (1981), que existe envolto em sua sócio-historicidade constitutiva, o extralinguístico atuante nas relações de força dos enunciados, na produção de sentidos.

A polêmica é da arte, mas é, antes, da vida. A produção discursiva é situada e isso implica a presença do extralinguístico, dos papéis assumidos por essa exterioridade na constituição dos sujeitos e enunciados. Uma visão crítica da historiografia - história problema e história de baixo, por exemplo - e uma visão mais aprofundada da historicidade e dos elementos como memória, fato histórico, acontecimento, arquivo, que sustentam uma avaliação das relações entre discurso e história ${ }^{10}$. Essa busca interdisciplinar objetiva problematizar a situação, o tempo/espaço da produção discursiva, do contexto, das condições de produção dos sentidos, dos interdiscursos, as relações com a memória. Uma historiografia relevante, que remonta aos tempos dos Analles e reverbera na escrita de Gorender, De Decca, Mota, Schwarc, Mota e muitos outros autores brasileiros. É essa historiografia que contextualiza diálogos, enunciados e as leituras.

O papel relevante da sociologia dá-se, de modo sistemático, com a determinação social dos discursos, dos estudos da sociedade e das categorias de grupo, conflito, ator social, movimento social, cultura política. Para o momento, buscamos uma compreensão de movimentos sociais a partir de Touraine (2009a, 2009b). Para o autor, os movimentos são condutas coletivas engajadas no conflito pela gestão da historicidade, o conflito deve estar no centro de uma análise da sociedade e o movimento social deve ser entendido como sujeito. Integram-se a essa visão, mas na perspectiva de novos movimentos sociais, no Brasil, autores como Gohn (2015 ) e outros. Sobre relações e movimentos sociais, em 1968, no Brasil, nos auxiliamos das referências de Cardoso (1990; 1998) e Fernandes (1982), além de dissertações e teses sobre o período e acontecimentos. Essa perspectiva de estudos é relevante exatamente porque coloca o conflito como constitutivo das trocas sociais que, integrados aos estudos discursivos, proporciona possibilidades de maior entendimento de atos e eventos de linguagem e das trocas verbais, do enunciado concreto e do dialogismo polêmico. Enfim, nas relações de poder nas quais os discursos são produ$\operatorname{zidos}^{11}$, mais as ideologias verificadas no heterodiscurso. Todos esses conhecimentos integram as condições necessárias para uma avaliação da produção discursiva e dos valores atuantes na vida social brasileira de 1968 e de hoje.

9 A teoria dialógica do discurso oferece condições para a análise da verbo-visualidade, como atestam os trabalhos de Brait $(2010 ; 2013)$ e outros. Por essa visão, devem ser recuperadas referências dos estudos da visualidade, articulada ao verbal, num único enunciado, e num único plano de expressão. Cabe, por isso, perguntar-se como estão articuladas e produzem sentidos.

10 As referências vão de Le Goff (2003) até as atuais tendências dos Annales, mais a historiografia marxista inglesa, que parte de Hobsbawn e Thompson até os novos pesquisadores dos movimentos sociais contemporâneos. Essa visada esclarece posicionamentos que atuam na feitura de nossos estudos.

11 Em Zandwais (2018), a autora apresenta uma reflexão sobre as relações entre discursos e poderes na contemporaneidade, buscando responder a questões como o que se pode entender por poder e em que domínios o poder é explicado, prevendo "ancorar tais relações em acontecimentos da atualidade que se discursivizam nos meios de comunicação”. 
Elementos para uma análise do dialogismo estão antecipados em Bakhtin-Volochinov (2004), na apresentação já de elementos de uma sintaxe das enunciações e os seus desdobramentos semânticos, os fenômenos citativos, o tema, a significação, os variados modos de apropriações do discurso do outro. Segundo Bakhtin (2003), o gênero polêmico é próprio do romance polifônico de Dostoiévski, muito importante na construção da narrativa. Por essa visão, a polêmica é um gênero primário e complexo da conversa informal. $\mathrm{O}$ dialogismo polêmico prevê essa conversa informal e se amplia para uma multiplicidade de gêneros discursivos, tais quais as palavras de ordem de um romance, o fotojornalismo e um post publicado recentemente nas redes sociais. A polêmica define-se como uma modalidade do discurso que encontra o seu espaço, a sua plenitude, sobretudo, na esfera política.

Por fim, segundo as ordens metodológicas, deve-se considerar a linguagem, pois os elementos linguístico-textuais são a parte visível da constituição do enunciado concreto. São a elementos linguísticos que Bakhtin-Voloshinov (2004) se referem ao falar de significação, e que estão presentes em Bakhtin (2003), em suas análises do enunciado linguístico e em outras partes da obra do Círculo. Essas referências apontam para dois caminhos: a textualidade e a argumentação ${ }^{12}$, motivo de debates sobre estudos do discurso e pragmática. Apenas para registrar, a semântica linguística de Ducrot não é incompatível, mesmo porque, em parte, deriva dela. É importante observar, por exemplo, o jogo posto/ pressuposto nos exemplos do exercício de leitura.

\section{Lili Passeata enfrenta o AI5}

No final do caminho, em dezembro, havia um AI5. Uma perspectiva para ler 1968, vem-nos de um enunciado produzido com o tema da democracia, das liberdades civis e do estado de direito, de uma narrativa ficcional. O romance Lili Passeata, do baiano Guido Guerra (1942-2005), publicado em 1978, narra a trajetória política de uma jovem conhecida como Lili Passeata, seus movimentos de rua e suas prisões: mulher, feminista, estudante, líder do movimento estudantil cujas pautas gerais representavam todos os movimentos de contestação ao golpe e ao regime instaurado a partir de 1964. Na narrativa, logo após a instauração do Ato Institucional $n^{0} 5$, Lili é presa e libertada, mas abandona a vida pública, todo e qualquer ativismo político, para viver uma mulher burguesa, esse final melancólico. Em meio a essa narrativa, e como parte dela, são muito relevantes os protestos de líder destemida de passeatas em Salvador, com suas palavras de ordem e outras falas, naqueles idos de 1968.

No romance, a última prisão de Lili acontece em dezembro de 1968, logo após a edição das novas normas da ordem pública. Em fotografia de um jornal local, Lili aparece em sua última passeata, empunhando um cartaz no qual se lê o enunciado: "AI5, funeral da democracia. Adeus liberdade!". É um enunciado porque expõe, para os manifestantes e a opinião pública, o ato recém-editado como a prova das novas normas e do endurecimento do regime ditatorial inaugurado em 1964. O cartaz e o AI5 estabelecem um diálogo mar-

12 Sobre as relações entre dialogismo e argumentação, pelo viés dos estudos da retórica e dos estudos bakhtinianos da polêmica, consideramos a tese de doutorado de Lucas Nascimento. Análise dialógica da argumentação: a polêmica entre afetivossexuais reformistas e cristãos tradicionalistas no espaço político (UFBA, 2018). 
cado, no qual o segundo atrai o primeiro, na tensão entre do regime político e finalidade social, em um funcionamento no qual o discurso do outro é atacado em seu próprio objeto (Bakhtin, 1981), ou seja, o objeto do enunciado é o objeto do enunciado outro.

Atos Institucionais são textos vigorosos, com sujeitos concretos, estabelecidos como um poder absoluto, totalitário, da esfera jurídica, de exceção, que estabelece novas regras de funcionamento social. De todos os atos, o AI5, atraído pelo enunciado do cartaz, possui as suas especificidades. É um texto de 8 páginas datilografadas, nas quais a última apresenta as assinaturas dos 15 ministros, dos 24 que aprovaram o referido Ato. É constituído de uma introdução/justificação, 12 artigos e 15 parágrafos que normatizam o funcionamento da vida política e social do Brasil. Na biografia do país, registra-se que "Foi imposto ao país numa conjuntura de inquietação política e movimentação oposicionista: manifestações estudantis, greves operárias, articulações de lideranças políticas do pré1964 e início das ações armadas por grupos da esquerda revolucionária" (SCHWARCZ; STARLING, p. 455). Por isso é considerado responsivo aos movimentos, mas com palavras próprias dos regimes ditatoriais.

O AI5 É um texto que possibilita, ao menos, duas leituras, a depender dos pontos de vista e valores que as orientam. É comum considerá-lo como um discurso de guerra: contra o inimigo da ordem pública, para o Estado; contra a democracia e as liberdades civis, para o enunciado do cartaz. Em meio a todo o aparato repressivo, a ação de Lili e o enunciado do cartaz questionam a ideologia, os conceitos e as práticas do outro.

Os "discursos Meia-Oito" referem-se à produção discursiva dos movimentos de resistência à ditadura, no cronotopo, a arena da luta pelos sentidos do regime democrático. $\mathrm{O}$ texto do Ato Institucional $\mathrm{n}^{\circ} 5$ é um enunciado concreto, situado, legislativo, jurídico, executivo. Em cada palavra, sentença, artigo, alínea, parágrafo lê-se a restrição, a ordem, a ameaça, a sentença, como ocorreu nos demais atos, mas o AI5 tem a particularidade de, pela lei e por todos os meios, transformar a não liberdade em liberdade, violentamente. Como sugere Bakhtin, esses textos devem ser colocados em uma perspectiva mais ampla da produção de sentidos, dimensão que se realiza no confronto de duas consciências, de dois interlocutores, de conjunção de discursos histórica, cultural e socialmente situados. O enunciado de Lili vale-se das metáfora comparadas aos princípios constitutivos dos sentidos produzidos pelo ato.

A história documenta que desde a edição e vigência do AIl, a "Operação Limpeza" já cassava mandatos, prendia, exilava e, para uma leitura do AI5, há de se considerar o conjunto dos dezessete atos editados até 1968 e mais outros documentos dos quais se apropria, autoritariamente, e as efetivas condições de suas edições. É, segundo o enunciado do cartaz, um documento que fere a constituição, que suplementa, suprime, muda, e a contradiz, com o fim único de legitimar ações políticas não previstas na lei maior. O Ato investe o governo de todos os poderes de intervir ilimitadamente, suspender, cassar e dá outras providências, radicalizando no uso desse poder ilimitado, restringindo a vida das pessoas a uma não liberdade, silenciamentos, banimentos, perseguições e apagamentos.

Uma grande parcela do povo brasileiro e da população de Salvador, da opinião pública da Bahia, compartilhavam, com Lili, o conhecimento de que o Brasil poderia se transformar em cárcere, pois o Ato oficializara e ampliara o regime ditatorial e o poder ilimitado dos militares e polícias civis. Conheciam, ainda, as justificativas e os atos que advogavam a instalação do novo regime governamental. O novo golpe, ou "o golpe no golpe", justificava-se no combate "às ideologias contrárias às tradições de nosso povo"; 
"contra a corrupção", "atos nitidamente subversivos, oriundos dos mais distintos setores políticos e culturais (...) estão servindo de meios para combatê-la e destruí-la [revolução]". Era essa a nova situação vivida no país do romance e na Salvador de Lili.

O enunciado do cartaz, ao comparar o ato ao fim, morte e separação, ao identificá-lo com a morte da democracia e da liberdade, pode ser uma resposta ao todo do documento e, principalmente, aos Artigos $9^{\circ}$ (em defesa da revolução); $10^{\circ}$ (suspensão de habeas corpus); 11 (desrespeito ao poder judiciário); 12 (a instalação do tribunal militar). Uma das possibilidades de leitura é fazer o enunciado do cartaz dialogar com a expressão "dá outras providências", mais o Art. $9^{\circ} .:$ "O presidente da República poderá baixar Atos Complementares para a execução desse Ato Institucional, bem como adotar, se necessário à defesa da Revolução, as medidas previstas nas alíneas de e do Parágrafo $2^{\circ}$ do art. 152 da Constituição".

No enunciado do cartaz, a não democracia, a não liberdade, a supressão dos direitos, revelam-se na citação da Constituição, no AI5. Esclarece-se, por exemplo, que a oração "e dá outras providências" busca instituir, na prática, o Estado de Sitio. O cartaz de Lili questiona os referenciais do outro e protesta, ao apresentar uma resposta de leitura da democracia e de liberdade do Ato, como ditadura, conforme a avaliação do movimento estudantil, de outros movimentos sociais e da opinião pública. A expressão e "dá outras providências", nessa leitura, funciona como um grande guarda-chuva que protege todas as ações não previstas na lei, como a prática da tortura e o "pode tudo" o poder do estado, avaliação negativa compartilhada por parte da sociedade civil.

No referido protesto, o enunciado concreto tem como objeto o enunciado outro, em sua integralidade, com o fim de denegá-lo, de fazê-lo potencialmente falso, em sua totalidade. E o modo de apropriação do enunciado do outro é explícito, dá-se por meio da citação de sua sigla, reproduzida, topicalizada, modalizada, refratada. O cartaz atrai para a arena uma voz muito poderosa, a do regime, subsidiário do sistema global, de função executiva, cujo enunciado é atraído e traduzido em registro negativo, como um discurso totalitário, normativo e operacional. Para Lili, as vozes do regime são a expressão do poder absoluto e letal; para o regime, as outras vozes são um perigo para revolução.

$\mathrm{Na}$ denúncia da não liberdade, por suas palavras, Lili perdeu a liberdade. Essa retomada do AI5 contribui para compreender responsivamente, dialogicamente, o enunciado polêmico de Lili. Observe-se que o cartaz trabalha com o necessariamente outro, que é também linguagem, a alteridade constitutiva, com um o seu alvo reconhecido e com o qual se choca. Já o AI5 é uma lei que não permite recurso, é já uma sentença antecipada, que se faz cumprir pela força, alicerce do seu poder que pune e silencia. A denúncia e o protesto trazem, como resultado, a protagonista em condição de não liberdade, assim como interditaram o movimento estudantil e de outros movimentos, polêmicos e democráticos.

\section{Discursos meia oito em post de 2018}

O fotojornalismo exercia, em 1968, no Brasil, a função de registrar, presentificar e aproximar a cena e a notícia do leitor - poucas cidades possuíam sinal de televisão -, quando a leitura de jornais dominava como meio de informação ilustrado. Com a missão não de reproduzir ou representar, mas de tornar visível a realidade, Evandro Teixeira, um mestre do gênero, produziu fotografias que documentam a movimentação das ruas, as 
manifestações, as passeatas, a repressão policial, enfim, cenas cotidianas de ocupação do espaço público, registros que comprovam a existência de um 1968, no Brasil. Como diria o fotógrafo, um fotojornalismo de resistência.

O tema da ditadura retornou, recentemente, nas discussões sobre o atual momento da vida política e social do Brasil, em meio a polêmicas entre progressistas e conservadores, representados por novos grupos e movimentos nas redes sociais. Para esse relacionamento entre realidades e discursos de ontem e de hoje, de 1968 e 2018, fomos surpreendidos por um exemplo fotográfico, transformado em um texto verbo-visual por intervenção de algum internauta e repercutido por grupos ativistas. A fotografia de Evandro Teixeira vem sendo transformada em posts, com grande frequência e finalidades geralmente vinculadas à denúncia, resistência, combates, como nos discursos meia-oito. Ela registra a perseguição policial a um estudante de medicina, no centro Rio de Janeiro, publicada na capa do Jornal do Brasil, em 22 de junho de 1968. A reprodutibilidade, nas redes sociais, na blogosfera, demonstra a sua relevância como um registro legitimado, simbólico, do movimento estudantil e das movimentações da época, que é apropriado, de variados modos, como respostas a discursos dos poderes constituídos e seus apoiadores, contrários à democracia, hoje.

A fotografia narrativiza, produz o ato do registro, denota uma ocorrência. Em Santaella (2002) são explicados aspectos e elementos do paradigma fotográfico, que se refere às imagens que dependem de uma máquina para captação física do mundo visível: as qualidades plásticas, como enquadramento, luz, contrastes, ponto de vista, mera aparência; uma realidade física materializada no fotolito, singularmente, a se deixar ver pela composição da figura retratada: posição, perspectiva; a integridade de um exemplar enquadrado na classe de imagens fotojornalísticas, que tem a função de registrar acontecimentos, a fotografia denotada, como diz Barthes.

No resultado do ato de fotografar estado de coisas e pessoas, aparecem, em primeiro plano, três personagens, no cenário da rua, e outros figurantes ao fundo, com predominância da luz, que faz sobressair-se todos os elementos de sua composição. O desenho coreográfico é logo percebido como uma corrida de dois militares e um civil, de uma perseguição e provável queda. E o que parece impactar é a caçada humana, cassetetes em busca da presa, a corrida paralizada, o desequilíbrio, uma narrativa presumível e inconclusa. É o momento de uma realidade imediata, do flagrante de uma violência, registrado num realismo que atrai o olhar e o pensamento. Essa fotografia publicada faz parte de um movimento de refração da "revolução" como golpe ditatorial, com a censura e a intervenção nas redações, nas instituições e em todos os setores da vida social.

Um modo de surpreender o post é verificar o inter-relacionamento entre o verbal e o visual, e como se dá o envolvimento de um com o outro em um processo de citação, de integração de duas vozes, de dois textos em um mesmo enunciado e os sentidos produzidos com essa composição, da fotografia capturada pelo enunciado verbal, muito recorrente, quase um slogan. O gênero integra o visual e o verbal e os resignifica em novo texto e discurso. Barthes (1982) apresenta uma discussão sobre a fotografia jornalística, da denotação e conotação ligada às relações entre a imagem e o texto verbal, da interdependência. O registro fotográfico de um fato considerado histórico se ressignifica na interação com os prováveis sentidos do enunciado "Ditadura nunca mais!", também ressignificado. Essa fotografia de 1968 é citada com certas intenções, na composição do enunciado concreto e no novo gênero, por vozes de grupos e redes virtuais, própria das novas textualidades digitais, da hibridização entre fotojornalísmo e a palavra de ordem, ou entre o visual e o 
verbal, muito comum na blogosfera. A fotografia informa que o Brasil vivenciou a violência do estado, tempo em que o medo, o terror, o perigo determinava toda a vida social, com perseguições, punições e interdições. O enunciado verbal exprime uma reação ao tempo da imagem, não de 1968 e da resistência, mas de um tempo de golpes.

Em suas lições sobre o enunciado e o gênero, Bakhtin (2003) diz que quando escolhemos as palavras, tiramo-las de outros enunciados congêneres com o nosso, pelo tema, pela composição, pelo estilo e que selecionamos as palavras segundo a sua especificação de gênero. Diz também que "na comunicação discursiva, existem tipos bastante padronizados e muito difundidos de enunciações valorativas, isto é, de gêneros valorativos de discurso que traduzem elogio, aprovação, êxtase, insulto" ( p. 291). O post, especialmente em sua parte verbal, apresenta o tom apropriado de uma reação ao que já foi antes; ao dito antes, como em uma resposta antecipada ou retardada, na composição de um discurso político da atualidade. Uma escolha que retoma dois enunciados na composição do todo, de um discurso combatente. O post responde a vozes golpistas de ontem e de hoje e os leitores entendem bem isso, uma situação reconhecida.

Trata-se de um enunciado de ampla circulação, muito comentado e compartilhado, principalmente em 2018, por conta das comemorações de 1968 e, após, como uma réplica a um ideário antidemocrático que proliferou antes, durante e depois das eleições presidenciais. Para um conhecedor da história desta fotografia, que sabe que foi capa do Jornal do Brasil, como registro da "Sexta-feira sangrenta", ocorrida no dia anterior"13, o sentido denotativo da fotografia, mais a conotação do enunciado verbal, produzem um diálogo entre o passado e o presente, como um novo movimento de resistência à força institucional. Para quem não a conhece, pode ser a imagem de uma perseguição, no passado, que deve estar relacionada à ditadura, palavra do enunciado, que não pode se repetir. Para os autores, os participantes do movimento e leitores mais conhecedores da situação, o alvo são os enunciados de ódio, que negam a democracia e defendem golpes e uma nova ditadura, produzidos a partir de uma memória discursiva atuante pré 1964 e 1968. O enunciado "Ditadura nunca mais", cita a imagem, na composição de um texto único, como um alerta para violência praticada desde o golpe de 1964 aos dias atuais, para refutar vozes contrárias à democracia. O terceiro da polêmica são os que tiveram acesso ao texto e o compartilham em suas redes e entre os seus seguidores. A fotografia é de 1968, mas o enunciado é de 2018 e a negação de vozes antidemocráticas se revela no todo do enunciado.

O funcionamento polêmico, a negação do objeto do discurso antagônico, apresenta um elemento relevante: a expressão "nunca mais", que significa não repetir em nenhuma hipótese, e que apresenta o pressuposto da existência de ditaduras passadas. Discursivamente, pode ser considerada como recusa antecipada, uma negação enfatizada numa temporalidade, de um tempo sem retorno, uma referência à própria fotografia, que se refere à ditadura em 1968. A expressão "nunca mais" retoma a memória de um tempo vivenciado, discursos e ações institucionais, da época, para recusá-los até mesmo como hipótese. É ela que, efetivamente, nega o discurso do outro, e, com isso, produz uma apreciação ao regime e responde a enunciados mobilizados em defesa da ditadura e pró-intervenção militar. $\mathrm{O}$ discurso meia-oito de agora constrói-se na dissonância entre a democracia em exercício e

13 Sobre os registros fotográficos ver ALVES, F.A. "Sexta-feira sangrenta" nas lentes do Jornal do Brasil: as representações dos personagens pelas fotochoques. MÉTIS - história e cultura. v. 16, n. 31. UCS: Jan./Jun. 2017. p. $97-126$. 
a ditadura de ontem, contra-argumentando com a imagem, fixando a legenda "ditadura" para concluir pela inaceitabilidade do regime político e de quaisquer práticas autoritárias.

A expressão "nunca mais" cuja memória remete a "Brasil: nunca mais", relato para a história da ditadura militar, responde, ainda, às palavras do AI5, retomadas por movimentos que defendem a tortura e torturadores. São enunciados produzidos por forças sociais que controlam os poderes, conquistados por golpes e pela força e continuam reproduzindo lições aprendidas no contexto da guerra fria, em que uma das armas mais poderosa é traduzir democracia, cidadania e soberania como socialismo, esquerdismo e comunismo. $\mathrm{O}$ autor e leitor conhecem as consequências dos anos de chumbo para a vida brasileira, uma herança de nunca acabar. Esses diálogos contratuais e polêmicos são significativos na constituição do enunciado e na produção da leitura, porque estabelecem as redes dialógicas, os interdiscursos.

Destaque-se, sempre, a importância histórica e da memória da fotografia que, entre tantas outras, foi uma das escolhidas para ilustrar a primeira página do jornal da época. No todo de uma materialidade significante, a fotografia é a prova, e o todo do enunciado incita a adesão de uma tese que consiste na avaliação da história política recente. $\mathrm{O}$ enunciado é polêmico porque cita uma imagem exemplar da ditadura militar como argumento para rejeitá-la; porque enfatiza a existência de uma ditadura no Brasil; e porque denega, em sua apreciação, todos os discursos que sugerem ou pregam seu retorno. O enunciado dialoga, também, com a biografia do Brasil e a história da ditadura: "Era uma máquina de matar concebida para obedecer a uma lógica de combate: acabar com o inimigo antes que ele adquirisse capacidade de luta. Atuava de maneira metódica e coordenada, variando em termos de intensidade, âmbito e abrangência geográfica" (SCHWARCZ; STARLING, 2025: 61).

Como diz Bakhtin (1981), dois sentidos materializados não podem estar lado a lado como dois objetos: devem tocar-se internamente, ou seja, entrar em relação comunicativa e esse é o princípio da interação e do dialogismo. Os temas da democracia, das liberdades civis, do estado de direito são constitutivos das trocas comunicativas entre grupos e movimentos que disputam sentidos verdadeiros para esses temas. $\mathrm{O}$ enunciado é polêmico porque é um discurso político que defende a sua verdade, inclusive de exercitar essa modalidade discursiva própria dos regimes democráticos. O post é polêmico por ser produzido por movimentações de grupos nas redes sociais com a intenção de opor-se à censura, violência policial, ameaças, perseguição, fechamento de conselhos participativos, misoginia, homofobia, xenofobia e demais valores defendidos até pelo próprio presidente da república.

Como o enunciado do cartaz de Lili, o exemplo verbo-visual traduz como ditadura aquilo que o regime diz ser democracia, liberdade e cidadania. A polêmica aberta é própria dos regimes democráticos e o post é um exemplo muito significativo pois retoma um discurso do passado para ativar uma memória histórica da resistência e da violência, do ano que nunca acabou, como condição para dialogar de modo polêmico, aberto e ativo com discursos autoritários do nosso tempo.

\section{Considerações finais}

Em “O discurso em Dostoiévski”, Bakhtin (1981) apresenta uma esquematização das ocorrências do discurso bivocal como a paródia e a polêmica, e afirma que não havia esgotado nem todas as ocorrências, nem todos os modos possíveis de apreensão do discurso 
do outro: "É possível uma classificação mais profunda e sutil com um grande número de variedades e possivelmente de tons". Diz, ainda, que as relações de reciprocidade com a palavra do outro no contexto vivo e concreto não tem caráter estático, mas dinâmico porque a inter-relação das vozes no discurso pode variar acentuadamente. Essas observações devem orientar para que se verifique o alcance da polêmica, suas variações, seus tons, sua potência no espaço público e até mesmo a metamorfose para o discurso autoritário e de ódio, que ignora o discurso e deseja a exterminação física do outro. Eis possibilidades que estimulam estudar o dialogismo polêmico.

A importância de tematizara vida social brasileira e sua produção de linguagem é adquirir conhecimentos que contribuam para o entendimento de sua organização histórico-social, suas práticas, suas relações e seus poderes, numa previsão do aprimoramento do seu funcionamento. Essa vida social pode ser avaliada por sua produção discursiva, pode ser revelada pela leitura dos discursos que produz. A leitura dos enunciados concretos faz perceber que a "guerra metafórica" é prática democrática de linguagem, necessária ao funcionamento da democracia, por uma alteridade que é seu princípio e que permite dialogar as diversidades, as identidades e identificações, a vida política, os conflitos sociais, as gramáticas de resistência.

No romance, as vozes possíveis, reivindicam, denunciam e protestam. Em seu enunciado, Lili parece ter a percepção de que a edição do AI-5 representa o fim do movimento estudantil e dos movimentos sociais em geral, e da polêmica, o seu silenciamento, a eliminação da voz, do corpo e da modalidade discursiva. Com ele e a partir dele não há mais nenhuma possibilidade de dialogismo. Os discursos ditatoriais tematizam a guerra anticomunista, a corrupção, a ordem pública, a defesa de supostas democracia e liberdade e sentenciam palavras e corpos dissonantes. O cartaz de Lili é a última tentativa de contrapor-se a um discurso absolutamente hostil que, com força de lei, é autoritário, ditatorial, do ódio que, destrói a polêmica e a democracia.

A fotografia de Teixeira é um enunciado definidor do movimento de 1968, no Brasil, considerada um documento histórico. Exemplo denotativo, integra o post como registro da violência do regime ditatorial. Visto e replicado por milhares de internautas conectados em redes e movimentos, responde a discursos que defendem a ditadura, produzidos por grupos que se auto-qualificam de extrema-direita. E essa resposta, resultante de avaliações, denega todo o sistema de valores dessa extrema-direita, por meio de uma polêmica aberta que legitima o seu outro antagônico, respeita a sua existência, mas se insurge contrariamente às tentativas de negação da história e a memória, do golpe, da ditadura e dos prejuízos à vida dos indivíduos e da sociedade. No regime democrático de hoje, exerce o direito e a liberdade de polemizar.

Em sua Semantique de La polemique, Maingueneau desenvolve a noção de campo discursivo atualiza a coexistência de dois espaços constituído por dois posicionamentos. Destaca, ainda, a figura do auditório, de um terceiro, a quem caberá o juízo final. Em Apologie de La polemique, Amossy (2014) apresenta uma reflexão sobre a polêmica pública, do espaço público por ser nele que se desenvolvem os debates de questões conflituosas de interesse geral. Por isso, interessa-se pelo funcionamento e suas funções dentro do espaço democrático, em uma sociedade pluralista. Em sua concepção, a polêmica se limita à esfera democrática, como uma modalidade argumentativa. Compreendemos, também, que essa possibilidade de ocupar um espaço de fala existe na democracia, em seu sentido mais amplo e usual, de ter direitos e deveres, garantidos o direito de dizer. Os polemistas têm 
direito e o poder para polemizar e tem de haver o reconhecimento do outro constitutivo. A arena do marxismo e filosofia da linguagem é o espaço da polêmica, da guerra metafórica, da luta democrática. A polêmica tem atualidade e é pública e o exame de suas relações constitutivas com o espaço público e a democracia ampliam as suas possibilidades.

Em diálogos com atos e eventos de 1968, com os movimentos, vemos retomados os temas da democracia e das finalidades e das lutas sociais geradores de trocas polêmicas, numa regularidade marcada no próprio ato de dizer, na modalidade discursiva própria dos regimes democráticos. Os discursos 68, de resistência, retomados nos discursos de hoje que presentificam a sua memória, devem ser lidos como produzidos no conflito da arena social em que vivemos, ontem e hoje.

Por essa compreensão, os discursos meia-oito são predominantemente polêmicos e os discursos do AI5 e de seus defensores, hoje, não o são, exatamente porque não amam a democracia. $\mathrm{O}$ ato é inequivocamente um documento ditatorial e está à margem da polêmica, como um discurso pautado por um ideal autocrático. O discurso polêmico do enunciado do cartaz pressupõe a democracia como condição de existência. O discurso ditatorial pressupõe o terror como forma de controle social; o discurso polêmico do post nega o posto e o pressuposto, em um tempo em que há ainda muitos espaços de falas polêmicas, muitos enunciados em movimentos, nas ruas e nas redes sociais virtuais.

\section{Referências}

AMOSSY, Ruth. Apologie de la polémique. Paris: Presses Univesitaires de France, 2014.

Angenot, Marc. La Parole pamphlétaire. Typologie des discours modernes. Paris : Payot, 1982.

BAKHTIN, Mikhail. (VOLOCHÍNOV). Marxismo e Filosofia da Linguagem. São Paulo: Hucitec, 2004.Tradução de Michel Lahud e Yara Frateschi Vieira. BAKHTIN, Mikhail. Estética da criação verbal. São Paulo: Martins Fontes, 2003. Tradução de P. Bezerra.

BAKHTINE, Mikhail. Pour une philosophie de l'acte. Paris: L'Age d'Homme, 2003a. Tradução de Ghislaine Capogna Bardet.

BAKHTIN, M. Questões de Literatura e de Estética: a teoria do romance. , São Paulo:Ed. UNESP - Hucitec, 1990. Tradução de Aurora Fornoni Bernardini.

BAKHTIN, Mikhail. Problemas da Poética de Dostoiévski. Rio de janeiro: ForenseUniversitária, 1981. Tradução de Paulo Bezerra.

BARTHES, Roland. L'obvie et l'obtus. Essais critiques III. Paris: Éditions Du Seuil, 1982.

BRAIT, Beth. Olhar e ver: verbo-visualidade em perspectiva dialógica. Bakhtiniana. São Paulo, v. 8, n. 2, p. 43-66, jul/dez. 2013.

BRAIT, Beth. Literatura e outras linguagens. São Paulo: Contexto, 2010.

BRAIT, Beth; MACHADO, Irene. O encontro privilegiado entre Bakhtin e Dostoiévski num subsolo. Bakhtiniana. São Paulo, v. 6 , n. 1, p. 24-43, ago/dez. 2011.

BURGER, Marcel. Les manifestes: paroles de combat. De Marx à Breton. Paris: Delachaux et Niestlé, 2002.

CARDOSO, Irene de Arruda Ribeiro. Memória de 68: terror e interdição do passado.

TempoSocial, v.2, n. 2. out. 1990. 
CARDOSO, Irene. 68: A comemoração impossível. Tempo Social. Revista de Sociologia da USP, S. Paulo, v. 10. n. 2, out. 1998.

FERNANDES, Florestan. A ditadura em questão. São Paulo: T. A. Queiroz Editor, 1982. GARAND, Dominique. Propositions méthodologiques pour l'étude du polemique. In: HAYWARD, Annette.; GARAND, Dominique. (Org.). États du polémique. Québec: Éditions Nota bene, 1998.

GOHN, Maria da Glória (org.). Movimentos sociais no início do século XXI: antigos e novos atores sociais. Petrópolis: Ed. Vozes, 2015.

GORENDER, Jacob. Combate nas trevas. A esquerda brasileira: das ilusões perdidas à luta armada. São Paulo: Ática, 1987.

GUERRA, Guido. Lili Passeata. Rio de Janeiro: Record, 1985.

KERBRAT-ORECCHIONI, Catherine. La polemique et ses définitions. GELAS, Nadine.; KERBRAT-ORECCHIONI, Catherine. (Org.). Le discours polémique. Lyon: Presses Universitaires de Lyon, 1980.

KURLANKY, Mark. 1968: o ano que abalou o mundo. Rio de Janeiro: José Olympio, 2005. Tradução de Sonia Coutinho.

LE GOFF, Jacques. Discurso e memória Campinas: Editora da Unicamp, 2003. Tradução de Irene Ferreira.

MAINGUENEAU, Dominique. Semantique de la polémique. Lousanne: L’Age d'Homme, 1983.

MAUÉS, Flamarion; ABRAMO, Zilahwendel. Pela democracia, contra o arbítrio. A oposição democrática, do golpe de 1964 à campanha das Diretas Já. São Paulo: Editora da Fundação Perseu Abramo, 2006.

PLANTIN, Christian. Des polémistes aux polémiqueurs. In: DECLERCQ, Gilles (Ed.). La parole polémique. Paris: Honoré Champion Éditeur, 2003.

SANTAELLA, Lucia. Semiótica aplicada. São Paulo: Pioneira Thomson Learning, 2002. SANTAELLA, Lucia; NÖTH, Winfried. Imagem. Cognição, semiótica, mídias. São Paulo: Iluminuras, 2001.

SANTOS, Elmo. Dialogismo e polêmica nas manifestações: "Os jovens de 1968 apoiam os jovens de 2013”. In: SANTOS, Elmo (Org.). Discursos e poderes: linguagem, teorias e análises. Salvador: EDUFBA, 2018.

SCHWARCZ, Lília Moritz; STARLING, Heloísa Murgel. Brasil: uma biografia. São Paulo: Companhia das Letras, 2015.

SILVA, Paulo Santos. Uma temporada de romances: a ditadura na prosa de ficção. In: CARDOSO, Lucileide Costa.; CARDOSO, Célia Costa (Orgs.). Ditaduras: memória, violência e silenciamento. Salvador: EDUFBA, 2017.

SOUZA, Geraldo Tadeu. Introdução à teoria do enunciado concreto de Bakhtin/ Volochinov/Medvedev. São Paulo: Humanitas, 2002.

TOURAINE, Alain. Crítica da modernidade. Petrópolis, Vozes, 2009. Tradução de Elia Ferreira Edel.

TOURAINE, Alain. Pensar outramente: o discurso interpretativo dominante. Petrópolis, Vozes, 2009. Tradução de Francisco Morás.

VOLOSHINOV, Valentin N. Le discours dans la vie et le discours dans la poésie. In: TODOROV, T. Mikhail Bakhtine. Le principe dialogique. Paris: Éditions du Seuil, 1981. . La structure de l'énonce. In. TODOROV, T. Mikhail Bakhtine. Le principe dialogique. Paris: Éditions du Seuil, 1981a. 
. A construção da enunciação e outros ensaios. São Carlos: Pedro \& João Editores, 2013. Tradução de João Wanderley Geraldi.

ZANDWAIS, Ana. O capital simbólico, o poder e o espaço do político: a administração dos sentidos na contemporaneidade. In: SANTOS, Elmo (org.). Discursos e poderes: linguagem, teorias e análises. Salvador: EDUFBA, 2018.

ZILBERBERG, Claude. Immanence et transcendance du polémique. In: Bulletin.

EHESS - CNRS. Paris. VII. Juin 1984.

Recebido em: 15/07/2019: Aceito em: 20/08/2019 